A obra e o legado de
John von Neumann 


\title{
A obra e o legado de John von Neumann
}

\author{
IMRE SIMON e UMBERTO G. CORDANI
}

$\mathrm{O}$ INSTITUTO DE ESTUdOS AVANÇAdos da Universidade de São Paulo e a Academia Brasileira de Ciências organizaram um encontro interdisciplinar para lembrar e debater a extraordinária obra e o legado do matemático húngaro-americano John von Neumann (1903-1957), cientista e pensador que contribuiu para um amplo espectro da ciência contemporânea.

O evento realizou-se no dia 14 de novembro de 1995 no Instituto de Matemática e Estatística da Universidade de São Paulo. Foram proferidas palestras situadas em cinco áreas distintas do conhecimento, a saber: Matemática, Computação, Economia, Física e Meteorologia. Tal é o espectro das principais contribuições científicas de John von Neumann.

O dossiê traz os textos levados ao colóquio e os comentários pessoais do coordenador do evento, Imre Simon. Inclui a palestra de Nicholas Vonneumann, irmão do ilustre cientista, que vive nos Estados Unidos e veio ao Brasil especialmente para participar da discussão. Chaim Samuel Hönig sintetizou a teoria da medida e outras contribuições de von Neumann para a Matemática. Ruy Exel analisou as idéias de von Neumann com relação à teoria de álgebras de operadores. Antônio Divino Moura falou da influência direta de von Neumann para a notável evolução da Meteorologia nas décadas de 40 e 50 . Tomasz Kowaltowski, em seguida, assinalou os fascinantes e complexos caminhos descobertos pelo cientista húngaro para a Ciência da Computação. Finalmente, Walter F. Wreszinski resumiu a originalidade das teses de von Neumann para a Física Matemática.

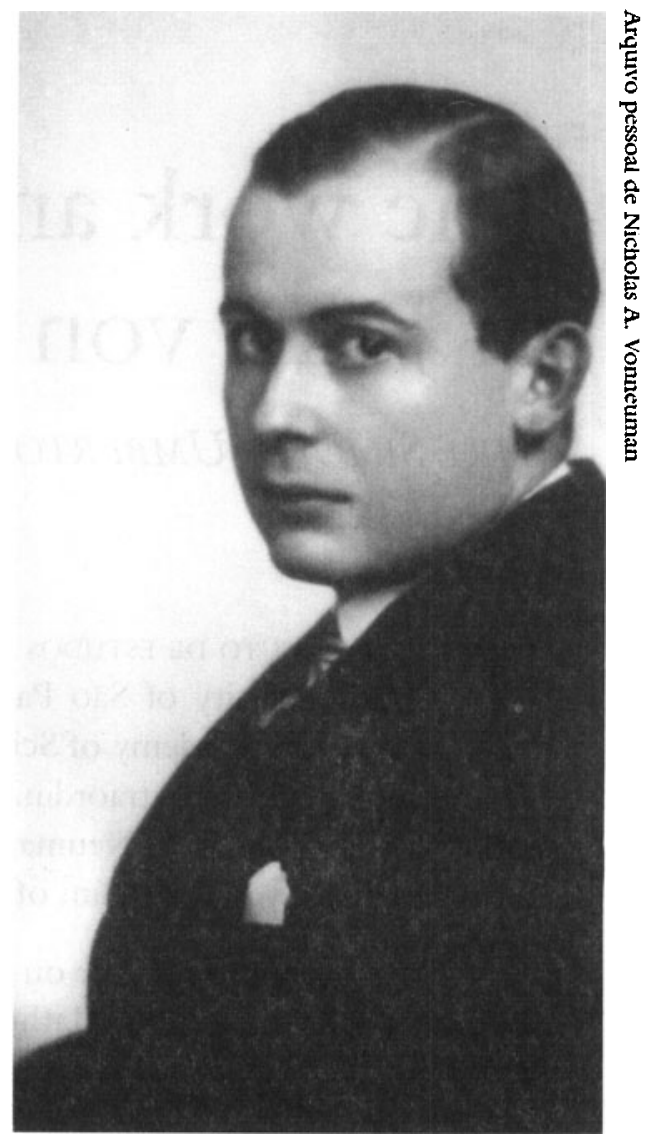

John von Neumann, em 1928 
Como conseqüência deste encontro, foi montada no Instituto de Matemática e Estatística uma página na teia World Wide Websobre John von Neumann, acessível no endereço http://www.ime.usp.br/, seguindo-se por Eventos $e$ Seminários e depois por A Obra e o Legado de Jobn von Neumann. Nesta página o visitante vai encontrar o programa do evento, o texto do colóquio, bem como apontadores para outras páginas na teia que tratam sobre o cientista e uma bibliografia eletrônica. A montagem destes meios eletrônicos de informação contou com a colaboração de Yoshiharu Kohayakawa, José Augusto Ramos Soares, Tomasz Kowaltowski e Jair Donadelli Júnior, a quem agradecemos.

Imre Simon é professor do Instituto de Matemática e Estatística da USP.

Umberto G. Cordani é diretor do Instituto de Estudos Avançados da USP e professor do Instituto de Geociências da USP.

\title{
The work and legacy of John von Neumann
}

\author{
IMRE SIMON e UMBERTO G. CORDANI
}

\footnotetext{
7 HE INSTITUTO DE ESTUdos AVANÇADOS [Institute of Advanced Studies] of the University of São Paulo and the Academia Brasileira de Ciências [Brazilian Academy of Sciences] organized an interdisciplinary meeting to recall and discuss the extraordinary work and legacy of the Hungarian-American mathematician John von Neumann (1903-1957), a scientist and thinker who contributed to a vast spectrum of contemporary science.

The meeting took place on November 14th at the Instituto de Matemática e Estatística [Institute of Mathematics and Statistics] of the University of São Paulo. Talks were deliveres in five different areas of learning, namely, Mathematics, Computer Science, Economics, Physics, and Metereology. Such is the spectrum of John von Neumann's main scientific contributions.
} 
This document, the von Neumann dossier, contains the texts presented at the meeting together with the personal remarks made by Imre Simon, the coordinator of the project. It includes the talk given by Nicholas Vonneumann, brother of the famous scientist, who lives in the USA and came to Brazil specially to participate in the panel's discussion. Chaim Samuel Hönig summarized the measure theory and other von Neumann contributions to Mathematics. Ruy Exel talked about the scientist's remarkable contributions to the theory of algebras of operators . Antônio Divino Moura analysed von Neumann's influence for the remarkable evolution of $\mathrm{Me}$ tereology in the 40's and 50's. Next, Tomasz Kowaltowski pointed out the fascinating and complex ways discovered by the Hungarian scientist or the field of Computer Science. Finally, Walter F. Wreszinski summed up the originality of the vonNeumann theses for Mathematical Physics.
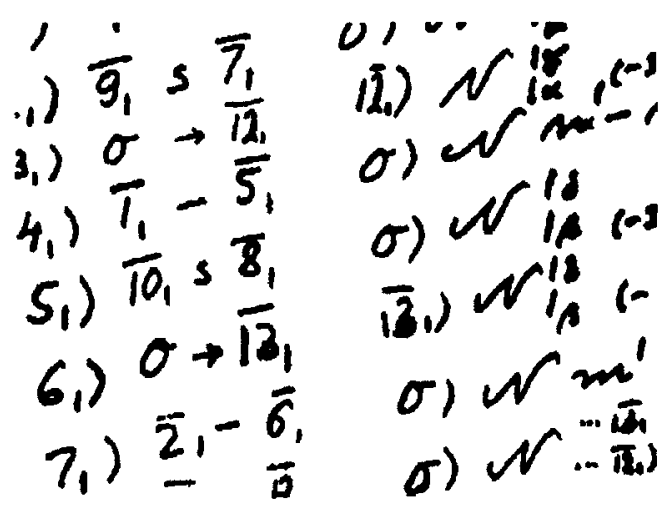

Manuscrito de pon Neumann

As a consequence of the meeting, a page of the Word Wide Web on John von Neumann was set up at the Instituto de Matemática e Estatística, accessible as http:/www.ime.usp.br./, followed by Events and Seminars and The Work and Legacy of Jobn von Neumann. On that page the user will access the program of the event, the text of its minutes as well as indicators to other pages in the net dealing with the scientist and to an eletronic bibliography on John von Neumann. The installation of these eletronic media was made possible through the collaboration of Yoshiharu Kohayakawa, José Augusto Ramos Soares, Tomasz Kowaltowski and Jair Donadelli Júnior, to whom we are thankful.

Imre Simon is professor of the Institute of Mathematics and Statistics of the University of São Paulo.

Umberto G. Cordani is director of the Advanced Studies Institute and professor of the Institute of Geosciences of the University of São Paulo. 


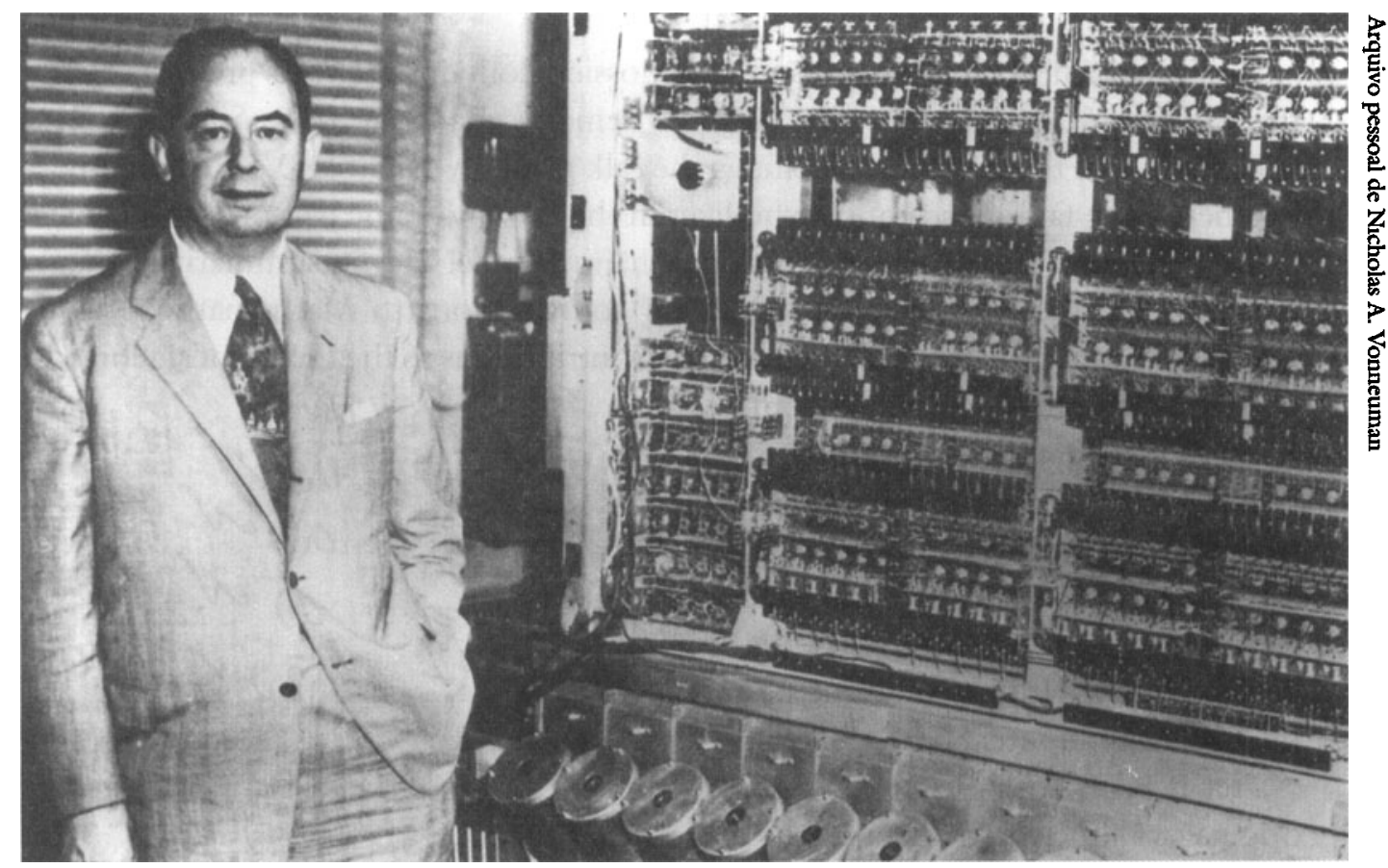

Jobn von Neumann (1903-1957) no Instituto de Estudo Avanf̧ado de Princenton (EUA), em 1952

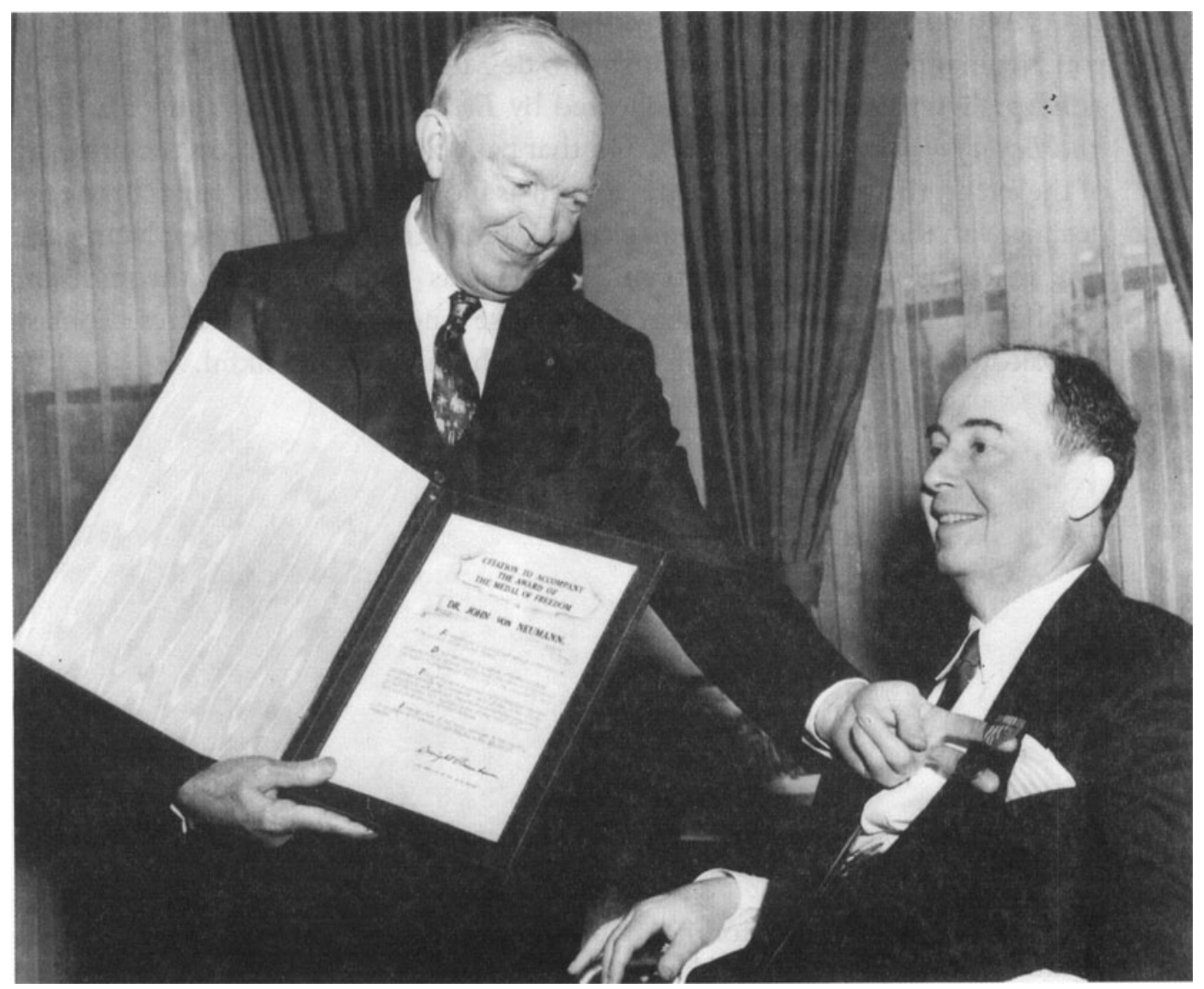

O presidente norte-americano Dwight Einsenhower entrega a Medalha da Liberdade a von Neumann, em 1956, na Casa Branca 